\title{
Electrochemical Sensors: A Powerful Tool in Analytical Chemistry
}

\author{
Nelson R. Stradiotto*, Hideko Yamanaka and Maria Valnice B. Zanoni \\ Instituto de Química, Universidade Estadual Paulista, CP 355, 14801-970 Araraquara - SP, Brazil
}

\begin{abstract}
Sensores potenciométricos, amperométricos e condutométricos são sensores eletroquímicos com imensa aplicação nas áreas de meio ambiente, indústria e análises clínicas. O presente trabalho apresenta uma revisão generalizada dos aspectos fundamentais, os desenvolvimento e a contribuição destes sensores na área de química analítica, e reporta alguns aspectos relevantes dos avanços na área de sensores eletroquímicos no Brasil.
\end{abstract}

Potentiometric, amperometric and conductometric electrochemical sensors have found a number of interesting applications in the areas of environmental, industrial, and clinical analyses. This review presents a general overview of the three main types of electrochemical sensors, describing fundamental aspects, developments and their contribution to the area of analytical chemistry, relating relevant aspects of the development of electrochemical sensors in Brazil.

Keywords: electrochemical sensors, amperometry, potentiometry, conductometry

\section{Introduction}

An overview of analytical chemistry development demonstrates that electrochemical sensors represent the most rapidly growing class of chemical sensors. A chemical sensor can be defined as a device that provides continuous information about its environment. Ideally, a chemical sensor provides a certain type of response directly related to the quantity of a specific chemical species. All chemical sensors consist of a transducer, with transforms the response into a detectable signal on modern instrumentation, and a chemically selective layer, which isolates the response of the analyte from its immediate environment. They can be classified according to the property to be determined as: electrical, optical, mass or thermal sensors and they are designed to detect and respond to an analyte in the gaseous, liquid or solid state. ${ }^{1}$ Compared to optical, mass and thermal sensors, electrochemical sensors are especially attractive because of their remarkable detectability, experimental simplicity and low cost. They have a leading position among the presently available sensors that have reached the commercial stage and which have found a vast range of important applications in the fields of clinical, industrial, environmental and agricultural analyses.

*e-mail: nrstradi@iq.unesp.br
There are three main types of electrochemical sensors: potentiometric, amperometric and conductometric. For potentiometric sensors, a local equilibrium is established at the sensor interface, where either the electrode or membrane potential is measured, and information about the composition of a sample is obtained from the potential difference between two electrodes. Amperometric sensors exploit the use of a potential applied between a reference and a working electrode, to cause the oxidation or reduction of an electroactive species; the resultant current is measured. On the other hand, conductometric sensors are involved with the measurement of conductivity at a series of frequencies. Given the impressive progress in the electrochemical sensor area, and their growing impact on analytical chemistry, it would be impossible in the context of this review to mention all the advances in electrochemical sensor research. Other review articles on electrochemical sensors are found in the literature. ${ }^{2-7}$ The main emphasis of this work is to provide a general overview of electrochemical sensors in a presentation of fundamental aspects and developments in a field in which a significant number of Brazilian researchers have been involved.

\section{Potentiometric Sensors}

Potentiometric sensors have found the most widespread practical applicability since the early 1930's, due to their simplicity, familiarity and cost. There are three basic types 
of potentiometric devices: ion- selective electrodes (IES), coated wire electrodes (CWES) and field effect transistors (FETS).

The ion selective electrode is an indicator electrode capable of selectively measuring the activity of a particular ionic species. In the classic configuration, such electrodes are mainly membrane-based devices, consisting of permselective ion-conducting materials, which separate the sample from the inside of the electrode. One electrode is the working electrode whose potential is determined by its environment. The second electrode is a reference electrode whose potential is fixed by a solution containing the ion of interest at a constant activity. Since the potential of the reference electrode is constant, the value of the potential difference (cell potential) can be related to the concentration of the dissolved ion. The detailed theory of the processes at the membrane interface, which generate the potential, is available elsewhere. ${ }^{8,9}$

Different strategies for producing an electrode that is selective to one species are based primarily on the nature and composition of the membrane material. Research in this area has opened up a whole series of applications to an almost unlimited number of analytes, where the only restriction is the selection of dopant and ionophore matrix of the membrane. Depending on the nature of the membrane, ISEs can be divided into three groups: glass, liquid or solid electrodes. More than two dozen ISEs are commercially available from Orion, Radiometer, Corning, Beckman, Hitachi and others, and they are widely used for the analysis of organic ions and of cationic or anionic species from various effluents, as well as in the manufacture and monitoring of drug, using selected response membrane electrodes. ${ }^{7,10}$

The most widely used potentiometric device is the $\mathrm{pH}$ electrode, which has been used for several decades. Its success is attributed to a series of undisputed advantages, such as simplicity, rapidity, nondestructiveness, low cost, applicability to a wide concentration range and, particularly, to its extremely high selectivity for hydrogen ions. Glass electrodes, based on a thin ion-sensitive glass membrane, are the most common and they are available in many shapes and sizes. Nevertheless, measurements of $\mathrm{pH}$ can also be performed using other types of potentiometric sensors. Application of glass electrodes for other monovalent cations, including sodium, lithium, ${ }^{11,12}$ amonium and potassium sensors based on new glass compositions, have also been reported. ${ }^{13}$ Although the use of glass membrane electrode to measure the $\mathrm{pH}$ of solutions, has had enormous success, its utilization is limited to measurements in aqueous media. Determinations of hydrogen ion in non aqueous solutions require corrections. ${ }^{14}$
Liquid-membrane-electrode ISE, based on waterimmiscible liquid substances impregnated in a polymeric membrane, are widely used for direct potentiometric measurements of several polyvalent cations as well as certain anions. The polymeric membrane is used to separate the test solution from the inner compartment containing a solution of the target ion. The membrane-active recognition can be by a liquid ion exchanger ${ }^{15}$ or by a neutral macrocyclic compound ${ }^{16}$ having molecule-sized dimensions containing cavities to surround the target ions.

Recent advances in the field can be illustrated by the work of some Brazilian research groups. A review about analytical applications of conducting polymers in potentiometric sensors has been published by Kubota and co-workers. ${ }^{17}$ The construction of a hydrogen ion-selective potentiometric electrode based on a tridodecylamine ionophore dispersed in a poly(vinylchloride) (PVC) membrane, ${ }^{18,19}$ or poly(1-aminoanthracene) films ${ }^{20}$ has been described. In addition, Rodwedder et $a .^{21}$ and Fatibello and co-workers ${ }^{22-25}$ have shown the use of coated graphite epoxy ion selective electrodes for determinaton of cations using ion-pair formation with tricaprylylmethylammonium cation in a PVC matrix. Using a similar system with incorporation of saccharinate anion and toluidine, Rover et al. ${ }^{26}$ have described the construction of a tubular ion selective electrode useful for determination of saccharin. A more sensitive system for saccharin determination has been described by Alfaya et al. ${ }^{27}$ using a thin film of silsesquioxane 3-n-propylpyridinium chloride polymer coated on a graphite rod. The successful use of thin film electrodes modified, by nickel(II) hexacyanoferrate, for potassium determination has been described by Stradiotto and co-workers. ${ }^{28}$ The construction and application of ion selective electrodes applied for determination of pharmaceutical compounds, such as acetylsalicylic acid and vitamin B-6, has also been described. ${ }^{29}$ The development of homogenous membrane tubular ion-selective electrode for cyanide determination was investigated by Queiroz and co-workers. ${ }^{30}$ Also a tubular ion selective electrode based on the ionophore nanoctin on PVC membrane is described for ammonium determination. ${ }^{31}$

An example of macrocyclic compound used for anion recognition was described by Stradiotto and co-workers ${ }^{16}$ These authors have developed novel acyclic ruthenium (II) bipyridyl complexes, shown in Figure 1, which were designed as receptor complexes and which were successfully applied as potentiometric sensors for chloride ions.

There is a growing interest devoted to the development of potentiometric sensors based on solid-state membranes. They can be made of single cristals, polycrystalline pellets, or mixed crystals that are selective to anions (e.g.; $\mathrm{F}^{-}, \mathrm{Cl}^{-}$, $\mathrm{Br}^{-}, \mathrm{I}^{-}, \mathrm{SCN}^{-}, \mathrm{S}^{2-}$ ) or cations (e.g.; $\left.\mathrm{Cd}^{2+}, \mathrm{Cu}^{2+}, \mathrm{Pb}^{2+}\right) .{ }^{15}$ 

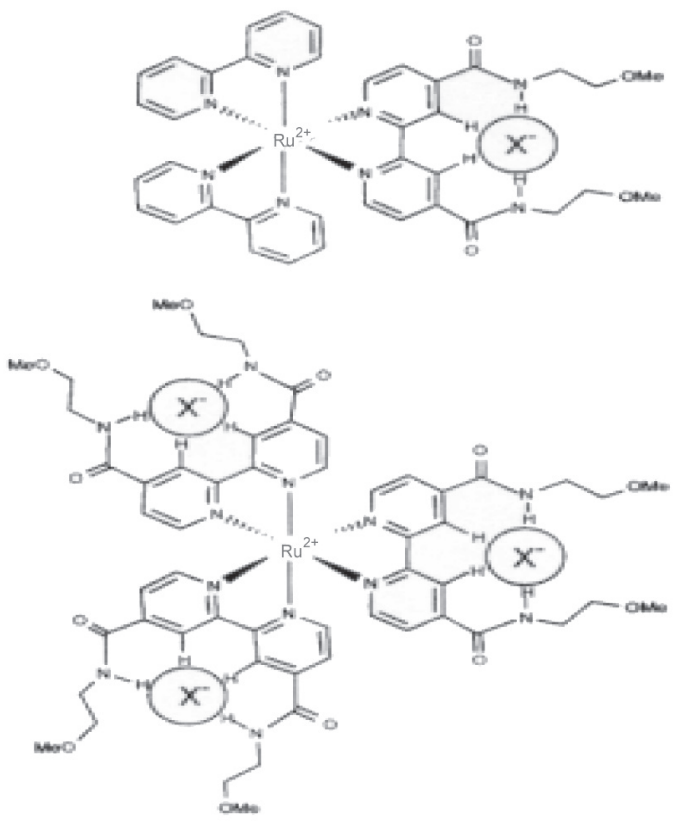

Figure 1. Schematic diagram of halide binding by $\left[\operatorname{RuL}(\text { bipy })_{2}\right]^{2+}$ and $\left[\mathrm{RuL}_{3}\right]^{2+}$.

Coated-wire electrodes (CWEs) were first introduced in the mid of 1970's by Freiser. ${ }^{32,33}$ In the classical CWE design, a conductor is directly coated with an appropriate ion-selective polymer membrane (usually poly(vinyl chloride, poly(vinylbenzyl chloride) or poly(acrylic acid) to form an electrode system that is sensitive to electrolyte concentrations. The CWE response $\mathrm{e}^{32-34}$ is similar to that of classical ISE, with regard to detectability and range of concentration. The great advantage is that the design eliminates the need for an internal reference electrode, resulting in benefits during miniaturization, for example. This is particularly useful for the in vitro and in vivo biomedical and clinical monitoring of different kind of analytes. ${ }^{32-34}$

Ion-selective field effect transistors (ISFET) work as an extension of CWE. ISFET incorporate the ion-sensing membrane directly on the gate area of a field effect transistor (FET). The FET is a solid-state device that exhibits highimput impedance and low-output impedance and therefore is capable of monitoring charge buildup on the ion-sensing membrane. The construction is based on the technology used to fabricate microelectronic chips, ${ }^{7,35-37}$ and the great contribution is that it is possible to prepare small multisensor systems with multiple gates, for sensing several ions simultaneously, while their small size permits the in vivo determination of analytes.

Alteration of the polymer matrix of potentiometric sensors by the immobilizaton of biological/biomedical materials has been pursued to alter the selectivity patterns of matrix ISE. Typical applications of these systems include enzyme determination and immunoassays. ${ }^{36,37}$ Enzyme electrodes are fabricated by immobilizing or covalenty binding an enzyme to an ion or gas-selective electrode or to an ISFET. The electrode will respond after the substrate diffuses to the immobilized enzyme and reacts. This reaction results in the release of a specific by product that can be detected directly by the ion-selective electrode. The success of the enzyme electrode depends, in part, on the immobilization of the enzyme layer, whose technology has experienced phenomenal growth in the recent years. ${ }^{7,36,37}$ An example is the use of laccase (enzyme label) for oxygen measurements. ${ }^{38}$

The immobilization of intact microorganisms on the surface of an ISE has also been described in the literature. ${ }^{7,36,37}$ In addition, potentiometric immunosensors have been developed, which are based on the change in potential when either an antibody or an antigen is bound to its specific partner that has been immobilized on the electrode. ${ }^{38}$

Recent advances can be illustrated by the use of carbon working and silver reference electrodes, supported in ceramic plates, for the analysis of human serum albumin (HSA)..$^{39}$ The anti-HSA IgG is adsorbed onto the surface of a thick-film electrode. After a competition between the bilabeled analyte-tracer and the analyte for the $\mathrm{Ab}$ sites, and removal of unbound tracer, $\mathrm{Bi}^{3+}$ is released, which can be detected by potentiometric stripping analysis ${ }^{39}$ after a preconcentration step.

Various on-line monitoring systems can benefit from the inherent specificity, wide scope, dynamic behavior and simplicity of potentiometric sensors. ${ }^{5}$ They have become widely used as detectors in high speed automated flow analyzers, such as air-segmented ${ }^{15,40}$ and flow-injection systems. ${ }^{41}$ In addition, the coupling of modern ion chromatography with potentiometric detection has been used with significant success. ${ }^{41,42}$ Miniaturization of ISE has also permitted their use as on-column detectors for capillary electrophoresis. ${ }^{43}$

Thus it is possible to conclude that potentiometric sensors have been important since 1930, when the commercialization of a glass electrode resulted in the foundation of one the most successful analytical instrument companies (Beckman Instruments). History also shown that, since 1960, when ion-selective electrodes revolutionized the approach to the difficult analysis of inorganic ions, up to now, the growth of patents for different formulations of glass, for different membrane types and for diverse shapes and sizes of electrodes testify to interest in the area. Therefore, there are many commercially 
available ion-sensing potentiometric devices. These systems tend to be low in cost, simple to use, easily automated for rapid sampling, with low interferences from the matrix, and can be applied to small volumes. These advantages make potentiometric sensors an ideal choice for both clinical and industrial measurements where speed, simplicity, and accuracy are essential.

\section{Amperometric Sensors}

"Amperometric sensor" is a term that is an anomaly in itself. In the context of electroanalytical techniques, amperometric measurements are made by recording the current flow in the cell at a single applied potential. On the other hand, a voltammetric measurement is made when the potential difference across an electrochemical cell is scanned from one preset value to another and the cell current is recorded as a function of the applied potential. In both cases, the essential operational feature of voltammetric or amperometric devices is the transfer of electrons to or from the analyte The basic instrumentation requires controlled-potential equipment and the electrochemical cell consists of two electrodes immersed in a suitable electrolyte. A more complex and usual arrangement involves the use of a three-electrode cell, one of the electrodes serving as a reference electrode. While the working electrode is the electrode at which the reaction of interest occurs, the reference electrode (e.g.; $\mathrm{Ag} / \mathrm{AgCl}$, $\mathrm{Hg} / \mathrm{Hg}_{2} \mathrm{Cl}_{2}$ ) provides a stable potential compared to the working electrode. An inert conducting material (e.g.; platinum, graphite) is usually used as auxiliary electrode. A supporting electrolyte is required in controlled-potential experiments to eliminate electromigration effects, decrease the resistance of the solution and maintain the ionic strength constant. The theoretical aspects and experimental procedures have been well documented. 6,7,15,44-46

In order to limit the scope of the definition of amperometric sensor to a reasonable range, this paper will not include studies on the mechanistic aspects involving electron-transfer reactions and electrode process. Although these studies are extremely important to amperometric sensor evolution, our discussion will concern itself only with the recent advances in quantitative amperometric sensors.

The performance of amperometric sensors is strongly influenced by the working electrode material. Consequently, much effort has been devoted to electrode fabrication and maintenance. Although classical electrochemical measurements of anaytes started in 1922, when Heyrovsky invented the dropping mercury electrode, for which he received a Nobel prize, solid electrodes constructed of noble metals and various forms of carbon have been the sensors of choice in recent years. The impressive progress in this area, and its growing impact on electroanalytical chemistry, is more recent. Research into electrochemical sensors is proceeding in a number of directions.

Mercury was very attractive as an electrode material for many years because it has an extended cathodic potential range window, high reproducibility and a renewable surface. The hanging mercury drop electrode or mercury film electrode was the most popular working electrode for stripping analysis. ${ }^{15}$ Numerous methods have been developed for determinations of metals, anions, organometallics and organic compounds by stripping analysis at concentration levels down to $1 \times 10^{-10} \mathrm{~mol} \mathrm{~L}^{-1}$ using a simple pre-concentration step. The limited anodic potential of mercury electrodes and its toxicity are the principal disadvantages of the method.

Solid electrodes (carbon, platinum, gold, silver, nickel, copper, dimensionally stable anions) have been very popular as electrode materials because of their versatile potential window, low background current, low cost, chemical inertness, and suitability for various sensing and detection applications. The proliferation of chemically modified electrodes (QME) generates a modern approach to electrode systems, where deliberate alteration of the electrode surface is introduced by incorporation of an appropriate surface modifier. While there was some progress in the development of amperometric sensors in the early 1970's, most amperometric sensors developed were applicable only to a controlled, stringent set of laboratory conditions.

Fortunately the miniaturization of the working electrode has gained much attention and microeletrodes (ME) were developed with dimensions not greater than $2 \mu \mathrm{m}$, increasing the possibility of in vivo and in vitro measurements with small apparatus. This resulted in a predictable boon for the development of amperometric sensors for real sample analysis. An example of this advance was the development of biossensors. They are capable of permitting a biospecific reagent, immobilized or retained at a suitable electrode, to convert the biological recognition process into a quantitative amperometric response. Particularly relevant is the coupling of sensitive amperometric sensors with liquid chromatography and flow injection systems. Finally, with the growing need to carry out decentralized analytical determinations remote from the laboratory, the development of screen-printed electrodes has provided modern amperometric sensors that are potentially portable. The new possibilities of design and fabrication of the electrodes, with the incorporation of microelectrodes, microelectrodes arrays, and chemically 
modified electrodes into various highly sensitive sensor systems (biosensors), has increased industrial and clinical interest. An overview of each of these contributions to electroanalysis is given below.

\subsection{Chemically modified electrodes}

Immobilisation of chemical microstrutures onto electrode surfaces has been a major growth area in electrochemistry in recent years. ${ }^{46-57}$ Chemically modified electrodes (CME) result from a deliberate immobilization of a modifier agent onto the electrode surface though chemical reactions, chemisorption, composite formation or polymer coating. Compared to conventional electrodes, greater control of electrode characteristics and reactivity is achieved by surface modificaton, since the immobilization transfers the physicochemical properties of the modifier to the electrode surface. Its application to electroanalysis is well documented in the literature. ${ }^{58-59}$

The interest in this area is motivated by the many potential applications of such a system. Examples include development of electrocatalytic systems with high chemical selectivity and activity, coating of semiconducting electrodes with photosensitising and anticorrosive properties, electrochromic displays, microelectrochemical devices for the field of molecular electronics and electrochemical sensors. The main benefits to analytical applications include acceleration of electrontransfer reactions, preferential accumulation, or selective membrane permeation and interferent exclusion. Such steps can impart higher selectivity, detectability and stability to amperometric devices, which have been extensively reviewed. . $^{39,52-54,58,59}$

One of the common approaches for incorporating a modifier onto the surface has been coverage with an appropriate polymer film. Most polymers are applied to electrode surfaces by a combination of adsorptive attraction and low solubility in the electrolyte solution, using preformed polymers or electrochemical polymerisation.

An early approach in the use of pre-formed polymers was their use as anchoring groups for coordinating metal complexes to pyrolytic graphite electrodes. ${ }^{55}$ Examples include poly(4-vinylpyridine) (PVP), poly(vinylferrocene) (PVF), poly(p-nitrostyrene), metalopolymers and others, used as redox monomers in polymer modification schemes after synthetic procedures. ${ }^{54,57}$

The advantages of preconcentrating CME were obtained by coating the electrode surface with a thin film of an ionexchange polymer. ${ }^{60}$ The strategy of coating an anionexchange polymer onto an electrode surface is similar to the stripping voltammetric method principle. This technique uses solid electrodes coated with a thin layer of an ionexchange polymer, which allows the quick pre-concentration and simultaneous amperometric detection of an ion redox analyte. The response depends on the concentration of electroactive species incorporated by ion exchange inside the polymeric layer. ${ }^{15,60}$ If an ion exchanger characterized by proper selectivity is used, it is possible to determine trace levels of ionic electroactive analytes (metals, pharmaceutical compounds, biological compounds) at submicromolar concentration levels. ${ }^{60-73}$ The most popular cation exchanging system is $\mathrm{Nafion}^{\circledR}$, although poly(styrene sulphonate), poly(vinyl sulphate), deprotonated poly(acrylic acid) and poly(-L-lysine), Tosflex, poly(vinylpyridine) and cellulose acetate have received significant attention. ${ }^{73-86}$ In addition, the preconcentrating agent also may acts as a permeselective coating, offering selectivity by exclusion from the surface of unwanted matrix constituents, while allowing transport of the target analyte. Pratical examples are obtained by use of size-exclusion coatings such as poly(diaminobenzene), ${ }^{87}$ hydrophobic lipid $^{88}$ or charged-exclusion ionomeric Nafion coatings. ${ }^{89}$ Electronically conducting polymers [such as poly(pyrrole), poly(thiophene), and poly(aniline)] have attracted considerable attention due to their ability to incorporate or expel ionic species during oxidative electro-polymerization of their monomers. The vast literature concerning fundamental investigations and proposed applications has been reviewed. ${ }^{90-99}$

Differents types of inorganic films, such as metal oxide, clay, zeolite, and metal ferrocyanide, can also be formed on electrode surfaces. These films are of interest because they frequently show well-defined structures, are thermally and chemically stable, and are usually inexpensive and readily available..$^{100-102}$

The improvements in selectivity and detectability due modifications of the electrode surface have been investigated by several Brazilian researchers. Serrano and co-workers ${ }^{103}$ have described the catalytic detection of NADH by using carbon paste electrodes coated by electropolymerized films of 3,4-dihidroxybenzaldehyde. Toma and co-workers ${ }^{104}$ also have shown the use of electrostatically assembled tetraruthenated cobalt and zinc porphyrin multi-layer films applied for the development of amperometric sensors. Kominsky and Bertotti ${ }^{105}$ have developed amperometric sensors based on electrodes modified by an electrochemically deposited molybdenum oxide layer and used them to determine some inorganic compounds. Kubota and co-workers ${ }^{106}$ have studied the construction and application of an amperometric sensor for dopamine using a glassy carbon electrode with a Nafion membrane doped with a (2,2'-bipyridil) copper (II) choride 
complex. Stradiotto and co-workers ${ }^{107}$ have reported a new way of modifying an electrode by combining vanadium pentoxide xerogel and a cationic surfactant able to detect anions, such as penatcyanonitrosylferrate (II) and hexacyanoferrate (III). Thin films of materials such as Prussian blue and related materials can be formed on the electrode surface and show interesting properties. ${ }^{102,107-110}$ Mattos and Gorton ${ }^{110}$ have shown that glucose biosensors can be constructed using Prussian blue films, with excellent performance. An example from Stradiotto and coworkers $^{101,102}$ of the use of Prussian blue films as an amperometric sensor to determine persulfate anions in hair bleach "booster" is shown in Figure 2.
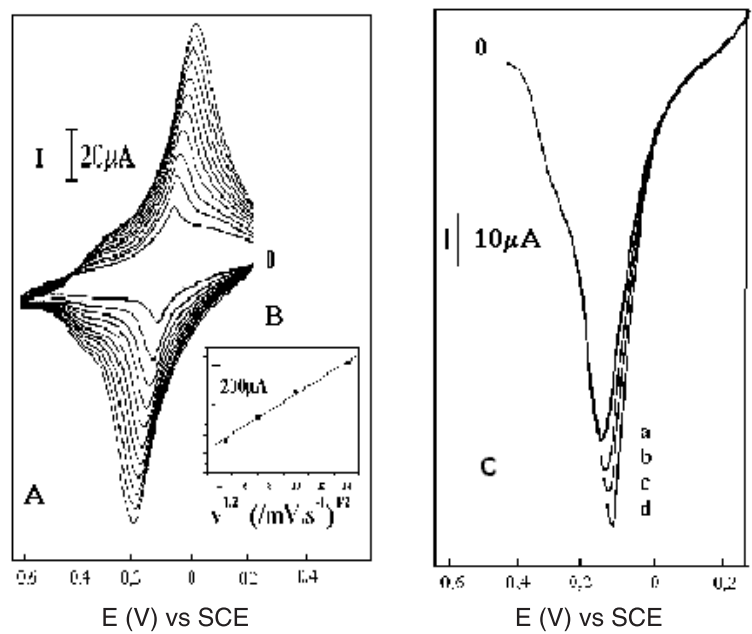

Figure 2. A) Formation of the Prussian blue (PB) film on a platinum electrode; $\mathrm{pH} 5$; $0.100 \mathrm{~mol} \mathrm{~L}^{-1} \mathrm{KCl}$ and $0.001 \mathrm{~mol} \mathrm{~L}^{-1}$ each of $\mathrm{K}_{3} \mathrm{Fe}(\mathrm{CN})_{6}$ and $\mathrm{FeCl}_{3}$; first 10 cycles at $100 \mathrm{mV} \mathrm{s}^{-1}$. Initial potential $0.20 \mathrm{~V}$. The steady current increase on potential cycling represents the formation of PB film. B) Diffusional electrochemical behaviour of PB film in $0.100 \mathrm{~mol} \mathrm{~L}^{-1} \mathrm{KCl}$. C)Determination of persulfate with a PB-modified electrode by the standard addition method $(n=100$ $\mathrm{mV} \mathrm{s}^{-1}$ ), a) blank; b) sample; c) $0.1 \mathrm{~mL}$; d) $0.2 \mathrm{~mL}$ of $0.100 \mathrm{~mol} \mathrm{~L}^{-1}$ $\mathrm{K}_{2} \mathrm{~S}_{2} \mathrm{O}_{8}$ solution.

These numerous studies, testify to the reliability of amperometric sensing devices as an electroanaytical technique ready to be used for solving real analytical problems. The extensive possibilities of application, as well as high selectivity in preconcentration and detection, makes these devices appropriate for analysis in complex samples.

\subsection{Amperometric biosensors}

Biosensors consist of a biological component (biochemical receptor) coupled to a transducer that will convert the biological into an electrical signal. A biological molecule, like an enzyme, cell, tissue slice, organelle, peptide, antibody, nucleic acid etc., ensures molecular recognition and may transform the analyte in some way. The electrochemical tranducer (potentiometric, amperometric or conductimetric), monitors the change in properties. The choice of transducer depends on the biological reaction. Molecular recognition could be accompanied by chemical conversion of the analyte to its respective products, which are determined by the biocatalytic sensor. In other cases, when an antibody is used, the biospecific recognition systems and interactions take place without analyte conversion, resulting in an affinity sensor.

As the electrochemical biosensor is a self-contained integrated device, ${ }^{111}$ the biochemical receptor should be retained in direct spatial contact with an electrochemical transduction element.

Clark and Lyons ${ }^{112}$ were the pioneers in indicating the possibility of using enzyme-containing membranes coupled to eletrodes. Updike and Hicks ${ }^{113}$ prepared the first biosensor by polymerizing a gel containing glucose oxidase onto a Clark oxygen electrode. Besides the entrapment of the biochemical receptor behind a membrane and within a polymeric matrix, the receptors could be immobilized within self-assembled monolayers (SAM) or bilayer lipid membranes (BLM), covalently bonded on membranes or previously activated surfaces or obtained through bulk modification of the entire electrode material. The biosensor lifetime depends on the stability of the immobilized material.

The first biosensor ${ }^{113}$ was proposed to oxidize glucose to gluconic acid using an electrode to amperometrically detect the consumption of oxygen, since its consumption is proportional to glucose concentration. Glucose oxidation actually uses a prosthetic group (flavin adenine dinucleotide - FAD) to transfer the electrons from the substrate. After substrate oxidation, $\mathrm{FADH}_{2}$ returns to $\mathrm{FAD}$ in the presence of oxygen. The electron acceptor (mediator$\mathrm{M}_{\mathrm{ox}}$ ) is reduced to $\mathrm{M}_{\mathrm{red}}$ by the cofator and then oxidized to $M_{\text {ox }}$ when in contact with the anode, which is polarized at the appropriate potential. This is the second-generation biosensor.

A more direct method is to have no mediator but a electrode on which the reduced enzyme can be directly oxidized. Kulys et al. ${ }^{114}$ suggested organic conducting salts to transfer electrons directly and are responsible for initiating third generation biosensors.

Investigations about construction, characterization and application of amperometric biosensors were initiated a long time ago in Brazil. Currently, several groups have introduced wide improvements in this field. An example 
is the amperometric biosensor for fructose detection developed by Kubota and co-workers ${ }^{115}$ using the immobilization of D-fructose 5-dehidrogenase on an electrode coated with polypyrrole film. Yamanaka and coworkers ${ }^{116}$ have demonstrated the development of an amperometric biosensor based on chlolinesterase for the determination of pesticides. The use of a sol-gel matrix to develop new biosensors has been reviewed by Alfaya and Kubota. ${ }^{117}$ Kubota and co-workers ${ }^{118}$ have also described a flow system method for continuous determination of phenolic compounds in environmental matrices employing lacase and tyrosinase-based biosensors as detector.s The use of a DNA biosensor has been investigated by Serrano and co-workers. ${ }^{119-120}$ The authors have demonstrated that the use of a DNA biosensor is a very promising tool for the investigation and study of the action of selected drugs. Mattos et al. ${ }^{109}$ have also developed glucose biosensors using the enzyme glucose oxidase immobilized on Prussian blue films electrodeposited on glassy carbon electrodes. The analytical use of vegetable tissue or crude extracts as enzymatic sources has been extensively studied by Fatibello and co-workers ${ }^{121-125}$ and by Angnes and coworkers. ${ }^{126}$ Examples of many biosensors and/or flow injection procedures for analysis of compounds of biological, environmental, food, pharmaceutical and industrial interest habe been described using vegetable tissues or crude extracts from sweet potato, ${ }^{122}$ avocado, ${ }^{123}$ zucchini, peach, yam, cassava, artichoke, turnip, horseradish, ${ }^{124,125}$ and tissues from fruits of the palm tree latania sp. ${ }^{126}$

A wide variety of compounds can be analyzed with an amperometric biosensor, according to the bioreceptor chosen. Instead of the pure redox enzymes, organelles (chloroplasts, mitochondria), animal and vegetable tissues or microorganisms can be immobilized onto the transducer. Recently, mimetic molecules have also been suggested, instead of enzymes or antibodies. ${ }^{127,128}$

The interaction between the antibody $\left(\mathrm{A}_{\mathrm{b}}\right)$ and antigen $\left(\mathrm{A}_{\mathrm{g}}\right)$ is characterised by its affinity constant, $\mathrm{K}$, defined by the equilibrium concentrations of the $\mathrm{A}_{\mathrm{b}}-\mathrm{A}_{\mathrm{g}}$ complex, the free analyte and the free antibody binding sites (where $\mathrm{K}=$ $\left.\left[\mathrm{A}_{\mathrm{b}}-\mathrm{A}_{\mathrm{g}}\right] /\left[\mathrm{A}_{\mathrm{b}}\right]\left[\mathrm{A}_{\mathrm{g}}\right]\right)$. Antibody reversibly binds antigen or hapten with high affinity constants between $5 \times 10^{4}$ and $10^{12} \mathrm{~L} \mathrm{~mol}^{-1}$. The extreme affinity of antigen-antbody interactions results in great detectability using these immunoassay methods.

As the physicochemical changes caused by the binding of the analyte to the biomolecule are usually very slight, in many cases auxiliary reactions have to be coupled. Indirect methods are based on labeling one of the immunochemical reaction partners with an enzyme, catalyst, fluorophore, electroactive substance or liposome. ${ }^{129}$ In indirect sensors, the free conjugate must be separated from the immunoreagent-bound conjugate before the marker activity can be measured.

There are different schemes of immunoassay ${ }^{130,131}$ and the most useful for immunosensors are the sandwich and the competitive binding reactions. A sandwich format uses an $A_{b}$ covalently immobilized onto the surface of the sensor, the test sample is incubated and, after washing, the complex is further exposed to a second marked $A_{b}$. Good detectability is reached with this format but it can not be applied to small molecules, because it is difficult for them to have more than one determinant epitope.

In the competitive case, antigen determination by competitive binding assays with labeled antigen is used. A known amount of labeled antigen is added to a sample with an unknown antigen concentration. When this mixture reacts with the $A_{b}$ immobilized at the transducer surface labeled antigen and antigen from the sample (unlabeled antigen) compete for the binding sites of the antibody. The affinity of antibodies for labeled antigen is usually lower than their affinity for unlabeled (free) antigen, owing to steric factors. After removal of all unbound antigen in the washing step, the amount of bound labeled antigen is determined through an enzyme-catalyzed reaction. The higher the quantity of $A_{g}$ in the sample, the lower is the fraction of labeled antigen in the $\mathrm{A}_{\mathrm{g}}-\mathrm{A}_{\mathrm{b}}$ complex. The final stage of this immunoasssay format is in fact the quantitative detection of the label. ${ }^{132}$

Yamanaka and co-workers has been contributed to the field of immunoassay development in Brazil, ${ }^{128,131}$ where investigations of biosensors based on the reaction between antigen and antibody coupled to an amperometric transducer are currently in progress. An example ${ }^{131}$ of the monitoring of the peroxide (POD) labeled antigen complexed with Ab immobilized onto the electrode surface is shown in Figure 3.

Overviews about enzyme labels suitable for amperometric, potentiometric and conductimetric

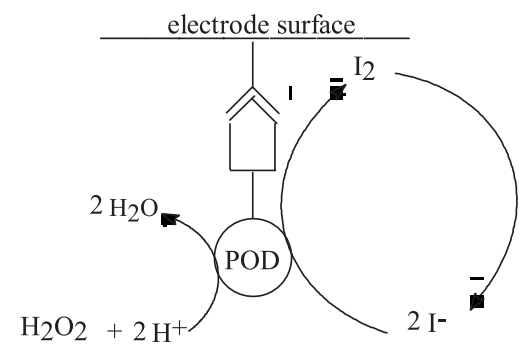

Figure 3. Scheme of the reaction catalyzed by peroxidase (POD-Ag complexed with the immobilized $\mathrm{Ab}$ ) and reduction of iodine at the electrode surface. 
detection are found in the literature. ${ }^{127-128}$ Examples of applications of immuno devices in clinical medicine and in environmental monitoring are also given, but virtually unlimited areas of application exist in food analysis and various other industrial processes.

\subsection{Other versatile amperometric devices}

3.3.1 Microelectrodes. The need for amperometric sensors with small dimensions has induced extensive investigations on the use of microelectrode systems. The miniaturization of the working electrode was first proposed by Wightman ${ }^{133-135}$ for the in vivo and in vitro determination of neurotransmitters. Nevertheless, microelectrodes exhibit several other attractive possibilities, including the exploration of microscopic domains, detection in microflow system, time-resolved probing of processes in single cells, the in vivo monitoring of neurochemical events (e.g. dopamine release) and analyses of very small sample volumes. ${ }^{136}$

Electrodes of different materials have been miniaturized in many geometrical shapes, with the common characteristic that the electrode dimension is significantly smaller than the diffusion layer at their surface. Due to the greatly reduced double-layer capacitance of microelectrodes, associated with their small area, and radial diffusion to the edges of microelectrodes, the signal-to-background characteristics are much better than with conventional electrodes. Because of their geometries and low current intensities, it is possible to work in highly resistive situations, including low dielectric solvents, at low temperature, in the gas phase, with ionically conductive polymers, with oil-based lubrificants and with solutions without addition of a supporting electrolyte.

Such dimensions offer obvious analytical advantages. Fine metal (Pt, Au, Ir) wires, carbon fibers or thin metal films are commonly used for these preparations. The geometric characteristics of the microeletrodes lead to analytical methods developed using a simple droplet $(\mu \mathrm{L})$.

In Brazil, some groups have extensively contributed to the development of this area. Machado, Avacca and coworkers ${ }^{137-139}$ have reviewed some theoretical aspects and studied the utilization of $\mathrm{Pt}, \mathrm{Co}$, or Ni-Co microelectrodes (UME) to characterize copper electrocrystallization and hydrogen evolution. Mori and Bertotti ${ }^{140}$ have investigated the chemical reaction between nitrite and iodide by using microelectrodes and Cavalheiro and co-workers ${ }^{141}$ have shown the application of nanostructured carbon fiber disk microelectrodes for determination of adenosine and uric acid in physiological buffers. Nevertheless, the most successful works in these area are published by Angnes and co-workers. ${ }^{142,143}$ These authors have described a notable performance of gold electrodes constructed from recordable CDs. The versatile, economic and very sensitive electrodes are applied for quantification of several organic and inorganic compounds. Stradiotto and co-workers ${ }^{144}$ have also used microelectrodes applied to small volumes. An example is shown in Figure 4, where the detection of sulfide ions on renewable drops of ferricyanide ions is obtained on a platinum microelectrode. ${ }^{144}$
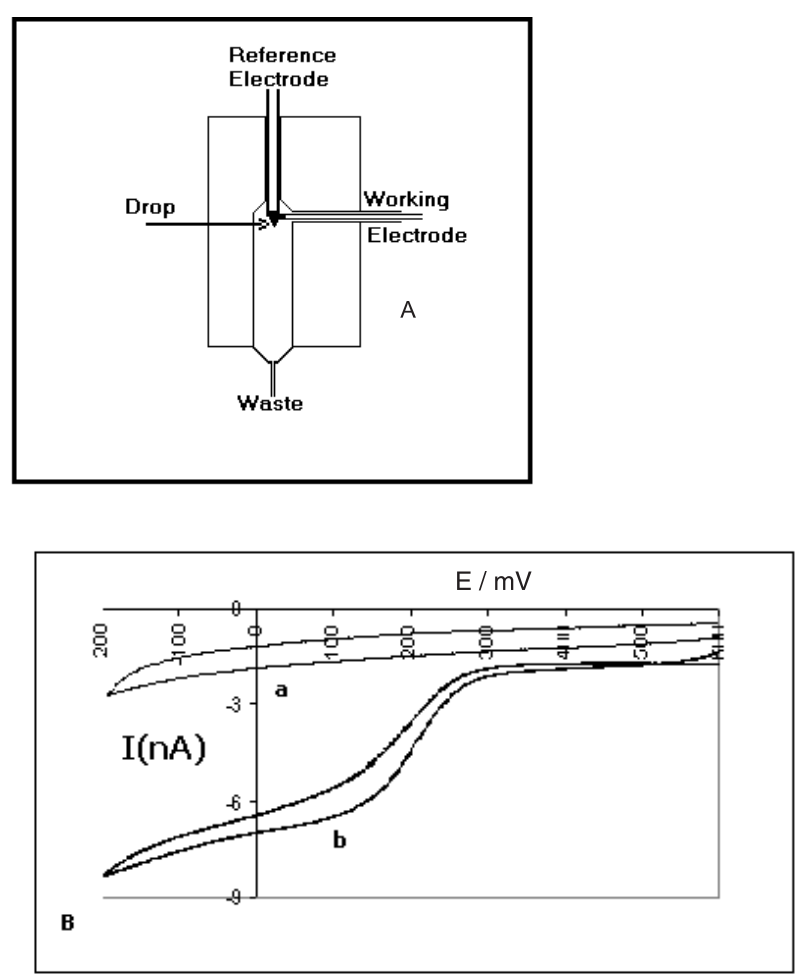

Figure 4. A) Stand used to hold the electrodes and to form drops. Drops of solution can be continuously formed on the tip of the reference electrode $(\mathrm{Ag} / \mathrm{AgCl})$, while the working electrode ( $\mathrm{Pt}$ microdisk) is inserted onto it; B) Cyclic voltammograms for a drop of $1 \mathrm{~mol} \mathrm{~L}^{-1}$ potassium chloride solution (curve a) and $510^{-3} \mathrm{~mol} \mathrm{~L}^{-1}$ potassium ferricyanide solution (curve b) on the microelectrodes.

The potential for use of UME in biological fluids has been dramatically increased with chemical modifications, such as ion-exchange polymers that have made their applicability in biological fluids more viable..$^{7,15,145,146}$ The charged membranes are selective for specific ions and reduce the interference of proteins and other materials indigenous to the physiological system.

Recently, arrangements of surfaces containing several microelectrodes with small dimensions, has gained attention. ${ }^{146-149}$ The surface is obtained with uniform (array) or random (emsemble) dispersion of a conductor in an insulating matrix. Such surfaces consist of spaced microdisks or ensembles fabricated by deposition of a metal conductor 
into the pores of a microporous host membrane. ${ }^{150}$ Nanoelectrode emsembles (NEE) have improved selectivity because the Faradaic current is proportional to the total geometric area while the background current depends on the sum of areas of the electrode elements in the NEE. As a result, they present a large collective current and have became a very promising area. In Brazil, Angnes and coworkers, ${ }^{151}$ Pasquini and co-workers, ${ }^{152}$ Fungaro and Brett ${ }^{153}$ and Fertonani et al. ${ }^{154}$ have contributed to the design and application of these devices.

3.3.2. Screen printed electrodes. The demand for easy to use, portable electroanalytical sensors, providing the opportunity to perform clinical, environmental or industrial analyses away from a centralized laboratory, seems to have been fulfilled with screen printing technology. ${ }^{150,155-157}$

Screen printing is a simple process for reproducibly and inexpensively depositing electrode substrates onto inert backing supports, usually PVC or ceramic materials. In general, the support is coated with a conducting ink, which is recovered by a second film with isolating characteristics with the aim to define an electrical contact at the extremities and other useful areas related to the electrode surfaces (working, reference and auxiliary electrodes). They are potentially portable, simple to operate, reliable, and inexpensive to manufacture. ${ }^{157-162}$ Many ink-type substrates have been used for sensor construction, ${ }^{155,163-165}$ the most successful have included carbon and the noble metals. Taking into consideration that carbon is inexpensive and conductive, it is the most used substrate for the economic fabrication of electrodes. Screen-printing equipment and inks for screen printed preparations are commercially available ${ }^{156}$ and applications in a variety of situations are described in the literature. ${ }^{116-120}$

Chemically modified electrodes may also be produced by incorporating specific reagents into the screen-printing inks, increasing the selectivity and detectability of measurements. The modest cost of screen printed electrodes, coupled with their versatility allow the production of disposable devices, which are relevant to industrial laboratories. ${ }^{166-168}$

Amperometric sensors based on screen printed electrodes have shown promise and successful applications for the determination of several naturally occurring biomolecular drugs, potential environmental toxins and industrial pollutants. Angnes and co-workers ${ }^{171,177}$ and Hart et al. ${ }^{156,157}$ have published excellent reviews describing in more depth some theoretical aspects and methods involving screen printed electrodes, unmodified or modified, for determination of such important organic compounds as ascorbic acid, uric acid, glucose, paracetamol, salicylic acid, ethanol, cholesterol, DNA, and environmental pollutants such as formaldehyde, hydrazines, nitrite, phenol, pesticides and herbicides and some metals. Recently, Kubota and co-workers ${ }^{172}$ have also described the use of a simple laccase-based screen-printed electrode for monitoring phenolic compounds in environmental samples.

In conclusion, screen printed electrodes are widely accepted in analytical chemistry as disposable electrochemical sensors, providing rapid and simple analytical determinations. Numerous devices based on screenprinting have matured to commercial success. For example blood glucose determinations using screen printed electrochemical sensors may now be viewed as the technique of choice for personal monitoring.

\subsection{Automated flow systems}

Automation within the clinical or industrial laboratory has seen major improvements in speed, reproducibility, cost, simplicity, and versatility. Applications of electrochemical detectors in automated flow systems have gained popularity in recent years. Such detectors have been particularly useful in connection with liquid chromatography and flow injection systems.

Amperometric detection is usually performed by controlling the potential of the working electrode at a fixed value and monitoring the current as a function of time. The magnitude of the peak current serves as a measure of the analyte concentration that passed through the detector. The potentiometric detector was discussed previously.

The coupling of electrochemical sensors to automated flow methods; segmented flow analysis (discrete segments divided by air bubbles) or flow injection analysis (FIA), where there is an unsegmented flowing stream into which reproducible sample volumes are injected, have combined the possibility of on-line sample pre-treatment aimed to isolate the analyte with the high good detectabillity of amperometric detection.

A wide range of cell designs and flow-injections systems using amperometric detection have been investigated by Gutz and co-workers ${ }^{173-175}$ and Angnes and co-workers. ${ }^{176-178}$ These authors have used amperometric detectors based on both thin-layer and wall-jet configurations. It is possible to employ many types, from mercury drop electrodes to carbonfiber microelectrodes, unmodified or with a modified surface capable of having electrocatalytic or preconcentration properties. A typical flow injection analysis of ascorbic acid in pharmaceutical compounds using amperometric detection with electrodes modified with Prussian blue films was 
developed by Stradiotto and co-workers, ${ }^{179}$ which are illustrated in Figure 5.

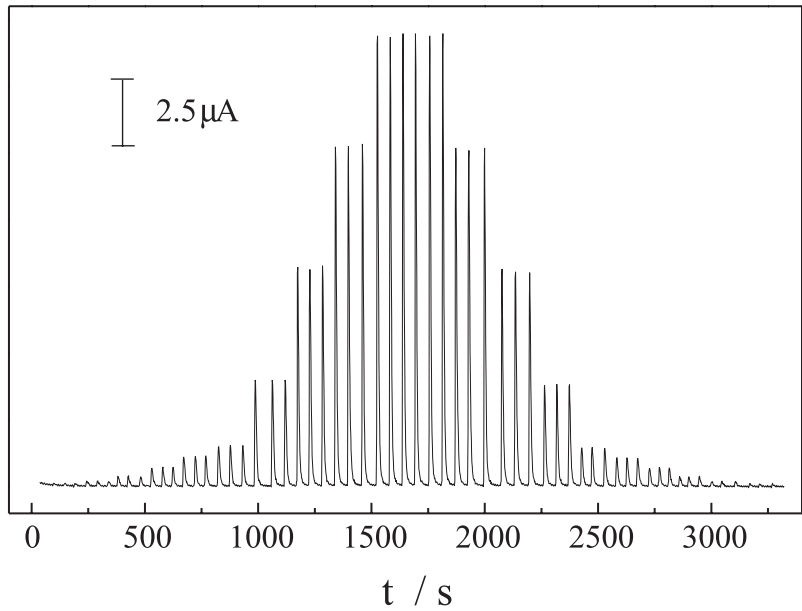

Figure 5. Flow injection amperometry for increasing and decreasing concentrations of ascorbic acid $(0.005,0.013,0.025,0.050,0.075$, $0.10,0.25,0.50,0.75$ and $\left.1.0 \mathrm{mmol} \mathrm{L}^{-1}\right)$ in a $1.0 \mathrm{~mol} \mathrm{~L}^{-1} \mathrm{KCl}(\mathrm{pH} \mathrm{3.7)}$ solution. Injection volume: $90 \mu \mathrm{L}$; flow-rate: $1.0 \mathrm{~mL} \mathrm{~min}^{-1}$. Applied potential: $0.27 \mathrm{~V}$.

The expansion of this research to incorporate the amperometric detector (highly sensitive and selective) into liquid chromatograph, adds the great advantage of a separation technique. Electrochemical detection is usually performed by controlling the potential of the working electrode, capable of reducing or oxidizing an electroactive analyte and monitoring the current as a function of the elution time. Taking into consideration that many organic compounds of biological, environmental or pharmaceutical interest present oxidable or reducible sites in their molecule, the applicability of electrochemical detection is enormous. The analytical capability of these detectors can be enhanced using surface modification and/or electrochemical procedures to increase the selectivity of the amperometric sensor or by using more than one working electrode operating simultaneously at different potentials using parallel detection. ${ }^{179,180}$ The power of electrochemical detection applied to capillary electrophoresis is also reviewed by Silva. ${ }^{181}$

\section{Conductometric Sensors}

Sensors in this group rely on changes of electric conductivity of a film or a bulk material, whose conductivity is affected by the analyte present. Conductimetric methods are fundamentally non-selective. Only with the advent of modified surfaces for selectivity and much improved instrumentation have these become more viable methods for designing sensors. There are some very practical considerations that make conductimetric methods attractive, such as low cost and simplicity, since no reference electrodes are needed. Improved instrumentation has contributed to rapid and easy determination of analytes, based only on the measurement of conductivity. The most predominant materials used in these sensors will be examined first. The methods of numerical processing of the analytical signal will then be discussed, followed by certain phenomena or properties which lend themselves to the purpose of sensing.

Thin films are used mostly as gas sensors, due to their conductivity changes following surface chemisorption. For example, due to oxygen chemisorption, $\mathrm{CdS}$ films can be used as oxygen sensors. ${ }^{182}$ Porous films of $\mathrm{MnWO}_{4}$ can work as a humidity sensor, ${ }^{183}$ oxides doped with copper or copper oxide can be very sensitive to gases containing $\mathrm{H}_{2} \mathrm{~S}^{184-187}$ and semiconducting $\mathrm{Ga}_{2} \mathrm{O}_{3}$ thin films can detect $\mathrm{CH}_{4} \cdot{ }^{187}$ Polymers, either conductive themselves or with a modifier, are also often used. Polypyrrole can detect volatile amines, ${ }^{188}$ or when doped with $\mathrm{ClO}_{4}^{-}$and tosylate, it can be made into a sensor for $\mathrm{NH}_{3} \cdot{ }^{188}$

Resistance measured from a DC current is typical. Often the measurement is done with $\mathrm{AC}$ current (impedance), which also allows one to obtain changes in capacitive impedance. ${ }^{189}$ For example zeolite layers can change the capacitance in response to the presence of combustion gases. ${ }^{190,191}$ Discrimination between conductivity and capacitance through impedance can extend the use of sensing materials. Impedance sensors were described for $\mathrm{NO}_{2}$ and tobacco smoke, ${ }^{192}$ odor detection ${ }^{193}$ or determination of water in an oil-in-water emulsion. ${ }^{194}$ Intelligent materials are frequently developed for this purpose. ${ }^{195,196}$

Humidity is very often a parameter for which mixed oxide conductivity sensors are used ${ }^{197,198}$ although it can also be an unwanted interference. A gas sensor for ethanol and acetone vapors, insensitive to humidity, can be based on sintered bismuth tungstate. ${ }^{199}$ Reports on the development of a multichannel aroma sensor are also found. ${ }^{193,200}$ Impedance measurements at various frequencies allow one to detect antibody-antigen binding. ${ }^{201,202}$

In Brazil, the advantages of the use of conductometric detection coupled to flow injection analyis was described by Jardim and co-workers ${ }^{203}$ to measure $\mathrm{CO}_{2}$ in the atmosphere. Fatibello and Borges ${ }^{204}$ have also shown a flow injection conductometric system appropriate to evaluate acidity in industrial hydrated ethyl alcohol. In addition, an automatic rain sensors based on a conductometric sensor was proposed by Gutz and co-workers, ${ }^{205}$ and Krug and co-workers. ${ }^{206}$ Tubino and Barros ${ }^{207}$ have also described a conductometric sensor coupled to a flow injection system to measure soil extracts and acidity in 
vinegars. Recently, the development of electrochemical sensors based on measurement of electrochemical admittance spectroscopy were also investigated by Stradiotto and co-workers. ${ }^{208}$ The application of $\mathrm{Ti}^{2} / \mathrm{TiO}_{2}$ electrodes for monitoring the content of nutrients in an artificial soil have shown excellent performance and it is used as an example in Figure 6.

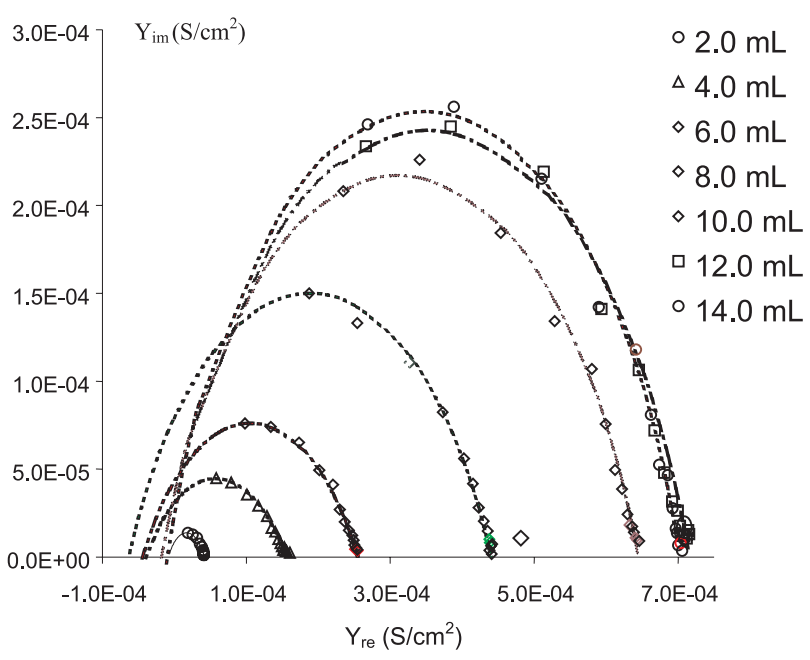

Figure 6. Admittance spectra as a function of the volume of nutrient added to a two-electrode cell containing $8 \mathrm{~g}$ of artificial soil. Area of working electrode $=4.5 \mathrm{~cm}^{2}$, DC potential $=+2.0 \mathrm{~V}, \mathrm{AC}$ potential $=$ $5 \mathrm{mV}$.

\section{Conclusions}

The interest in electrochemical sensors continues unabated, stimulated by the wide range of potential applications. There are several journals specializing in electrochemical sensors; large professional societies have electrochemical sensor divisions; and several series of international conferences on electrochemical sensors take place regularly, testifying to its importance inside chemistry and correlated areas. Their impact is also observed in chemical education, since chemical sensors have entered the analytical curricula at many universities. During the past 20 years, electrochemical sensors have become an accepted part of analytical chemistry, because they satisfy the expanding need for rapid, simple and economic methods of determination of many analytes.

The important basis of electrochemical knowledge obtained with the evolution of voltammetric and potentiometric techniques and the later development of electrochemical sensors has Brazilian contributions. The pioneering and significant work of some research groups (E.A. Neves, G.Oliveira Neto, E.R. Gonzales, L.A. Avaca, O.E.S. Godinho, M. Molina, C. B. Melios, R. Tokoro, T.
Rabóczkay, I.G.R. Gutz and others not cited but also important) was largely responsible for popularizing the electrochemical area in Brazil and the consequent widespread use of electrochemical sensors seen nowadays. Currently, many Brazilian workers are making significant contributions in the area and some representative works have been cited above related to the development of efficient instrumentation and automated systems, biosensors and immunosensors, screen printed electrodes, chemically modified electrodes, potentiometric sensors, microelectrodes and other advances applied for determination of inorganic, organic, pharmaceutical and biological compounds in diversified matrices. Their significant work should be consulted to obtain a wider picture of the development of the electrochemical sensors area in Brazil.

Finally, the challenge to researchers developing these important devices has always included the practical difficulty of establishing reproducible and inexpensive methods and simple to use routine analysis equipment. With such a vast range of possibilities as described here, it is easy to realize the significance and importance of electrochemical sensors to the evolution of analytical chemistry.

\section{Acknowledgements}

The authors would like to thank their co-workers and they are also grateful to CAPES, CNPq and FAPESP for their support.

\section{References}

1. Janata, J.; Anal. Chem. 2001, 73, 150A.

2. Hitchman, M.L.; Hill, H.A. O.; Chem. Brit. 1986, 22, 117.

3. Janata, J.; Bezegh, A.; Anal. Chem. 1988, 60, 62R.

4. Widrig, C.A.; Anal. Chem. 1990, 62, 1R.

5. Edmonds, T.E., ed.; Chemical Sensors, Chapman and Hall: New York, 1988

6. Janata, J.; Principles of Chemical Sensors, Plenum Press: New York, 1989.

7. Wang, J.; Electroanalytical Techniques in Clinical Chemistry and Laboratory Medicine, VCH: New York, 1988.

8. L.D. Bower;Carr, P.W.; Anal. Chem. 1976, 48, 545 A.

9. Weetall, H.H.; Anal. Chem. 1974, 46, 602A.

10. Covington, A. K., ed.; Ion Selective Electrode Methodology, CRC Press: Boca Raton, vol. 1-2, 1978.

11. Gadzekpo, V.P.Y;; Hungerford, J.M.; Kadry, A.M.; Ibrahim, Y.A.; Christian, G. D.; Anal. Chem. 1985, 57, 493.

12. Metzger, E.; Dohner, R.; Simon, W.; Vonderschmitt, D.J.; Gautschi, K.; Anal. Chem. 1987, 59, 1600. 
13. Eisenman, G., ed., Glass Electrodes for Hydrogen and Other Cations, Marcel Dekker: New York, 1976.

14. Galvão, D.; Stradiotto, N.R.; Talanta 1989, 36, 427.

15. Wang, J.; Analytical Electrochemistry, VCH: New York, 1994.

16. Beer, P. D.; Mortimer, R. J.; Stradiotto, N. R.; Szemes, F.; Weightman, J. S.; Anal. Proc. 1995, 32, 419.

17. Rover, L.; Oliveira Neto, G.; Kubota, L.T.; Quim. Nova 1997, 20, 519.

18. Martelli, P.B.; Reis, B.F.; Zagatto, E.A.G.; Lima, L.J.F.C.; Lapa, R.A.; Quim. Nova 1998, 21,133.

19. Martelli, P.B.; Reis, B.F.; Korn, M.; Lima, J.L.F.C.; Anal. Chim. Acta 1999, 387,165.

20. Faria, R.C.; Bulhões, L.O.S; Anal. Chim. Acta 1998, 377, 21.

21. Rohwedder, J.J.R.; Pasquini, C.; Raimundo, I.M.; Conceição, M.; Montenegro, B.S.M.; Araujo, A.N.; Couto,C.M.C. M.; J. Autom. Meth. Managem. Chem. 2002, 24, 105.

22. Teixeira, M.F. S.; Aniceto, C; Fatibello-Filho, O.; J. Braz. Chem. Soc. 1998, 9, 506.

23. Teixeira, M.F.S.; Fatibello-Filho, O.; Intern. J. Pharm. 2001, $221,115$.

24. Souza, M.F.; Fatibello-Filho, O.; Talanta 1997, 45, 249.

25. Fatibello-Filho, O.; Anicetto, C.; Lab. Robot. Autom. 1999, 11, 234.

26. Rover, L.; Garcia, C.A.B.; Oliveira Neto, G.; Kubota, L.T.; Galembeck, F.; Anal. Chim. Acta 1998, 366, 103.

27. Alfaya, R.V.S.; Alfaya, A.A.S.; Gushikem, Y.; Rath, S.; Anal. Lett. 2000, 33, 2859.

28. Mortimer, R.J.; Barbeira, P.J.S.; Sene, A.F.B.; Stradiotto, N.R.; Talanta 1999, 49, 271.

29. Fernandes, R.N.; Sales, M.G.F.; Reis, B.F.; Zagatto, E.A.G.; Araujo, A.N.; Montenegro, M.C.B.S.M.; J. Pharm. Biom. Anal. 2001, 25, 713.

30. Marin, M.A.B.; Silva, R.C.; Lehmkuhl, Silva; B.B., Ganzarolli; E.M., Queiroz; R.R.U.; Quim. Nova 2000, 23, 23.

31. Rover-Jr, L.; Oliveira Neto, G.; Lima. J.L.F.C.; Montenegro, M.C.B.S.M.; Quim. Nova 1996, 19, 549.

32. Freiser, H. , ed., Ion Selective Electrodes in Analytical Chemisty, Plenum Press: New York, 1980.

33. Freiser,H.; J.Chem. Soc. Faraday Trans. 1986, 82, 1217.

34. Cunningham, L.; Freiser, H.; Anal. Chem. 1982, 54, 1224.

35. Kelly, R. G.; Owen, A. E.; J. Chem. Soc. Faraday Trans. 1986, 1,1195

36. Gennett, T.; Purdy, W.C.; Am. Lab. 1991, 23 (6) 60.

37. Gennett, T.; Purdy, W. C.; Am. Lab. 1991, 23(3) 60.

38. Ghindilis, A. L.; Skorobogat'ko, O.V.; Gavrilova, V. P.; Yaropolov, A. I.; Biosens. Bioelec. 1992, 7, 301.

39. Wang, J.; Tian, B.; Rogers, K.R.; Anal.Chem. 1998, 70, 1682.

40. Toth, K.; Lindner, E.; Feher, Z.; Pungor, E.; Anal. Chim. Acta 1986, 179, 359.

41. Trojanowich, M.; Matuszewski, W.; Anal. Chim. Acta 1982, 138,71 .
42. Isidak, I.; Covington, A.; Electroanalysis 1993, 5, 815.

43. Nann, A.; Silvestri, I.; Simon, W.; Anal.Chem. 1993, 65, 1662.

44. Bard, A. J.; Faulkner L.; Electrochemical Methods, Wiley: New York, 1980.

45. Brett C.; Brett, A.M.O.; Electrochemistry: Principles, Methods and Applications, Oxford University Press: Oxford, 1993.

46. Smith, M.; Vos, J.; Analytical Voltammetry, Elsevier: Amsterdam, 1992.

47. Snell, K. D.; Keenan, A.G.; Chem. Soc. Rev. 1979, 8, 259.

48. R.W. Murray In Electroanalytical Chemistry. A Series of Advances; Bard,A.J., ed., Marcel Dekker: New York, 1984, vol. 13, p. 191.

49. Abruña, H. D.; Coord. Chem. Rev. 1986, 86, 135.

50. Hillman, A. R. In Electrochemical Science and Technology of Polymers; Linford, R.G., ed., Elsevier: London, 1987, vol. 1, pp. 103-292.

51. Lyons, M. E. G.; Annu. Rep. Prog. Chem., 1990 sect C, 87, 119.

52. Murray, R. W.; Ewing, A. G.; Durst, A.R.; Anal. Chem. 1987, 59, 379A.

53. Baldwin, R. P.; Thomsen, K. N.; Talanta 1991, 38, 645.

54. Wang, J.; Electroanalysis 1991, 3, 255.

55. Scott, N. S.; Oyama, N.; Anson,F. C.; J. Electroanal. Chem. 1980, 110, 303.

56. Merz, A.; Bard, A. J.; J. Am. Chem. Soc. 1978, 100, 3222

57. Wang, J.; Taha, Z.; Anal. Chem. 1990, 62, 1413.

58. Sousa, M.D.B.; Quim. Nova 1997, 20, 191.

59. Pereira, A.C.; Santos, A.D.; Kubota L.T.; Quim. Nova 2002, 25,1012 .

60. Ugo, P.; Moretto, L. M.; Electroanal. 1995, 7, 1105.

61. Hoyer, B.; Florence, T. M.; Batley, D. E.; Anal. Chem. 1987, 59, 1608.

62. Hoyer, B.; Florence, T. M.; Anal. Chem. 1987, 59, 2839.

63. Ugo, P.; Ballarin, B.; Daniele, S.; Mazzocchin, G. A.; Anal. Chim. Acta 1992, 29, 324

64. Kristensen, E. W.; Wightman, R. M.; Anal. Chem. 1987, 59, 1752 .

65. Crespi, F.; Martin, K. F.; Marsden, C. A.; Neuroscience 1988, 27,885 .

66. Dalangin, R. R.; Gunasingham, H.; Anal. Chim. Acta 1994, 291,81 .

67. Vidal, J. C.; Crepia, G.; Castillo, J. R.; Anal. Chim. Acta 1992, 259, 129.

68. Vidal, J. C.; Vinao, R. B.; Castillo, J. R.; Electroanalysis 1992, 4, 653.

69. Santos, M.M. C.; Capelo, S.; Gonçalves, M. L. S. S.; J. Electroanal. Chem. 1994 , 364, 171.

70. Gorski, W.; Cox J. A.; Anal. Chem. 1992, 64, 2706.

71. Boyd, D.; Rodriguez, J. R. B.; Ordieres, A. J. M.; Blanco, P. T.; Smith, M. R.; Analyst 1994, 119, 1979. 
72. Toniolo, R.; Bontempelli, G.; Schiavon, S.; Zotti, G.; J. Electroanal. Chem. 1993, 336, 67.

73. Liu, K. Z.; Wu, Q.; Electroanal. 1992, 4, 569.

74. Oyama, N.; Anson, F. C.; J. Electrochem. Soc. 1980, 127, 247.

75. Shigehara, K.; Oyama, N.; Anson, F. C.; Inorg. Chem. 1981, 20, 518.

76. Anson, F. C.; Savéant, J. M.; Shigehara, K.; J. Am. Chem. Soc. 1983, 105, 1096.

77. Rubstein, I.; Bard, A. J.; J. Am. Chem. Soc. 1980, 102, 6641.

78. Henning, T. P.; White, H. S.; Bard, A. J.; J. Am. Chem. Soc. 1981, 103, 3937.

79. White, H. S.; Leddy, J.; Bard, A. J.; J. Am. Chem. Soc. 1982, 104, 4811.

80. Martin, C. R.; Rubstein, I.; Bard,A. J.; J. Am. Chem. Soc. 1982,104, 4817.

81. Henning, T. P.; White, H. S.; Bard, A. J.; J. Am. Chem. Soc. 1982,104, 5862.

82. Butry, D. A.; Anson, F. C.; J. Electroanal. Chem. 1981, 130, 333.

83. Butry, D. A.; Anson, F. C.; J. Am Chem. Soc. 1982, 104, 4824.

84. Butry, D. A.; Anson,F. C.; J. Am Chem. Soc. 1983, 105, 685.

85. Oyama, N.; Oki, N.; Ohno, H.; Ohnuki, Y.; Matsuda, H.; Tsuchida, E.; J. Phys. Chem. 1983, 87, 3642.

86. Anson, F. C.; Tsou, Y. M.; Savéant, J. M.; J. Electroanal. Chem. 1984, 178, 113.

87. Sasso, S. V.; Pierce, R.; Walla, R.; Yacynych, A.; Anal. Chem. 1990, 62, 1111.

88. Wang, J.; Lu, Z.; Anal. Chem. 1990, 62, 826.

89. Nagy, G; Gehardt, G.; Oke, A.; Rice, M.; Adams, R. N.; J. Electroanal. Chem. 1985, 188, 85.

90. Chandler, G. K.; Pletcher, D.; Electrochemistry, Specialist Periodical Report, Royal Society of Chemistry: London, 1986, vol. 10, pp.117-150.

91. Skotheim, T.A., ed.; Handbook of Conducting Polymers, Marcel Dekker: New York, 1986, vols. 1-2.

92. Feast, W. J.; Conductive Polymers. Report from Rapra Review, Pergamon Press: Oxford, 1987, vol.1.

93. MacDiarmid, A. G.; Maxfield, M. In Electrochemical Science and Technology of Polymers; Linford, R. G., ed., Elsevier: London, 1987, vol. 1, pp. 67-101.

94. Deronzier, A.; Moutet, J. C.; Acc. Chem. Res. 1989, 22, 249.

95. Margolis, J. M., ed., Conductive Polymers and Plastics, Chapman and Hall: New York, 1989.

96. Evans, G. P. In Advances in Electrochemical Science and Engineering; Gerisher, H.; Tobias, C. W., eds., VCH: Weilheim, 1990, vol. 1, pp. 1-74.

97. Heize, J.; Top. Curr. Chem. 1990, 152, 1.

98. Simonet, J.; Rault-Berthelot,J.; Prog. Solid State Chem. 1991, 21,1 .

99. Imisides,M.D.; John,R.; Riley,P.J.; Wallace, G.G.; Electroanal. 1991, 3, 879 .
100. Itaya, K.; Uchida, I.;Neff, V. D.; Acc. Chem. Res. 1986, 19, 162.

101. Oliveira, M,F.;Mortimer, R, J; Stradiotto, N, R.; Microchem, J. 1999, 64, 155.

102. Mortimer, R. J.; Barbeira, P. J. S.; Sene, A. F. B.; Stradiotto, N. R.; Talanta 1999, 49, 271.

103. Delbem, M.F.; Baader, W.J.; Serrano, S.H.P.; Quim. Nova 2002, $25,741$.

104. Rocha, J.R.C.; Demets, G.J.F.; Bertotti, M.; Araki, K.; Toma, H.E.; J. Electroanal. Chem. 2002, 526, 69.

105. Kominsky, L.; Bertotti, M.; Electroanalysis 1999, 11, 623.

106. Sotomayor, M.D.; Tanaka, A.A.; Kubota, L.T.; Electrochim. Acta 2003, 48, 855.

107. Castro, S.S.L.; Balbo, V.R.; Barbeira, P.J.S.; Stradiotto, N.R.; Talanta 2001, 55, 249.

108. Silva, L.F.; Profeti, L.P.R.; Stradiotto, N.R.; Oliveira, H.P.; J. Non- Crystalline Sol. 2002, 298, 213.

109. Mattos, I.L.; Lukachova, L.V.; Gorton, L.; Laurell, T.; Karyakin, A.A.; Talanta 2001, 54, 963

110. Mattos, I.L.; Gorton, L.; Quim. Nova 2001, 24, 200.

111. Thévenot, D.R.; Toth, K.; Durst, R.A.; Wilson, G.S.; Pure Appl. Chem 1999. 71, 2333.

112. Clark L.C.; Lyons C.; Ann. N. Y. Acad. Sci. 1962,102, 29.

113. Updike, S.J.; Hicks, G.P., Nature 1967, 214, 986.

114. Kulys, J.J.; Samalins, A.S.; Svirmickas, G. J. S.; FEBS Letters 1980, $144,7$.

115. Garcia, C.A.B.; Neto, G.D; Kubota, L.T.; Anal. Chim. Acta 1998, $374,201$.

116. Nunes, G.S.; Skladal, P.; Yamnaka, H.; Barcelo, D.; Anal. Chim. Acta 1998, 362, 59

117. Alfaya, A.A.S.; Kubota, L.T.; Quim. Nova 2002, 25, 835.

118. Freire, R.S.; Duran, N.; Kubota, L.T.; J. Braz. Chem. Soc 2002, 13, 456.

119. Brett, A.M.O., Serrano, S.H.P.; Gutz, I.G.; LaScalea, M.A.; Bioeletrochem. Bioenerg.1997, 42, 175.

120. Brett, A.M.O.; Serrano, S.H.P.; Gutz, I., LaScalea, M.A.; Cruz, M.L.; Electroanalysis 1997, 9, 1132.

121. Fatibello-Filho, O.; Vieira, I.D.; Quim. Nova 2002, 25, 455.

122. Vieira, L.C.; Lupetti, K.O.; Fatibello-Filho, O.; Anal. Letters 2002, 35, 2221.

123. Fatibello-Filho, O.;Vieira, L.C.; Lupetti, K.O.; Talanta 2001, 55,685 .

124. Vieira, L.C.; Lupetti, K.O.; Fatibello-Filho, O.; Quim. Nova 2003, 26, 39

125. Vieira, I.D.; Fatibello-Filho, O.; Angnes, L.; Anal. Chim. Acta 1999, 398, 145

126. Lima, A.W.O.; Vidsiunas, E.K.; Nascimento, V.B.; Angnes, L.; Analyst 1998, 123, 2377.

127. Skladal P.; Electroanalysis 1997, 9, 737.

128. Riccardi, C.S.; Costa, P.I.; Yamanaka,; H.; Quim. Nova 2002, 25,316 . 
129. Aizawa, M. In Immunosensors, Biosensor Principles and Applications; Blum, L.J.; Coulet, P.R., ed., Marcel Dekker, Inc.: NewYork, 1991, pp.249-266.

130. Tijssen, P. In Practice and Theory of enzyme Immunoassays, Burdon, R.H.; van Knippenberg, P.H., ed., Elsevier: Amsterdam, 1985, vol. 15.

131. Yamanaka, H.; Skládal, P.; Anais Assoc. Bras. Quím. 2001, $50,28$.

132. Wilson, R.; Barker, M.H.; Schiffrin, D.J.; Abuknesha, R.; Biosens.Bioelec. 1997, 12, 4 .

133. Wightman, R. M.; Science 1988, $240,415$.

134. Wightman, R. M.; Neuroscience 1988, 25, 513.

135. Wightmn, R. M.; Anal. Chem. 1981, 53, 1125A.

136. Kennedy, R.; Huang, L.; Atkinson, M.; Dush, P.; Anal. Chem. 1993, 65, 1882.

137. Barin, C.S.; Correia, A.N.; Machado, S.A.S.; Avaca, L.A.; J. Braz. Chem. Soc. 2000, 11, 175.

138. Tavares, M.C.; Machado, S.A.S.; Mazo, L.H.; Electrochim. Acta 2001, 46, 4359.

139. Souza, D.; Machado, S.A.S.;Avaca, L.A.; Quim. Nova 2003, 26,81 .

140. Mori, V.; Bertotti, M.; Electroanal. 1999, 11, 234.

141. Brajter-Toth, A.; About E. N. K.; Cavalheiro, E.T.; Bravo, R.; Anal. Chem. 2000, 721576.

142. Angnes, L.; Richter, E.M.; Augelli, M.A.; Kume, G.H.; Anal. Chem. 2000, 72, 5503.

143. Richter, E.M.; Augelli, M.A.; Magarotto, S.; Angnes, L.; Electroanal. 2001, 13, 760 .

144. Milani, M.R.; Stradiotto,N.R.; Cardoso, A.A.; Electroanalysis $\mathbf{2 0 0 3}$, in press.

145. Mc Kean, B.D.; Gough, D. A.; Trans. Biomed. Eng. 1988, 35, 526.

146. Penner, R.; Martin, C.R.; Anal. Chem. 1983, 55, 1146.

147. Allman, D.E.; Petersen, S.L.; Electroanalysis 1990, 499, 2.

148. Bond, A.M.; Oldham,K.B.; Zoski,C.G.; Anal. Chim. Acta 1989, 216,177

149. Nascimento, V. B.; Augelli, M. A.; Pedroti, J. J.; Gutz, I. G. R.; Angnes, L; Electroanalysis 1997, 335, 9.

150. Brunetti, B.; Ugo, P.; Moretto, L.M.; Martin, C.R.; J. Electroanal. Chem., 2000, 491, 166.

151. Matos, R.C.; Augelli, M.A.; Lago, C.L.; Angnes, L.; Anal. Chim. Acta 2000, 404, 151.

152. Freire, R.S.; Rohwedder ,J.J.R.; Pasquini, C.; Analyst 1999, $124,1657$.

153. Fungaro,D.A.; Brett, C.M.A.; Anal. Chim. Acta 1999, 385, 257.

154. Faber, M.; Fertonani, F.L.; Yamanaka, H.; Benedetti, A.V.; Eclet. Quim. 2000, 25, 171.

155. Nascimento,V.B.; Agnes,L.; Quim. Nova 1998, 21, 614.

156. Hart, J.P; Wring,S.A.; Electroanalysis 1994, 6, 617.

157. Hart, J.P.; Trends Anal. Chem. 1997, 16, 89.

158. Wring, S. A.; Hart, J. P.; Birch, B. J.; Analyst 1992, 117, 1281.
159. Turner, A. P. F.; Wilson, G. S.; Karube, I., eds.; Biosensors: Fundamentals and Application, Blackie: Glasgow , 1987.

160. Hall, E.A.H.; Biosensors, Open University Press Milton: Keynes, England, 1990.

161. Hart, J. P.; Electroanalysis of Biologically Important Compounds, Ellis Horwood : Chicester, 1990.

162. Scheller,F.; Schubert, F.; Pfeiffer, D.; Hintsche, R.; Dransfeld, I.; Renneberg, R.; Wollenberger,U.; Reidel, K.; Pavlova, M.; Kuhn, M.; Muller, H. G.; Tan, P. M.; Hoffman, W.; Moritz,W.; Analyst 1989, 114, 653.

163. Wring, S. A.; Hart, J. P.; Bracey, L.; Birch,B. J.; Anal. Chim. Acta 1990, 231, 203.

164. Hart, J. P.; Wring, S. A.; Anal. Proc. 1991, $28,4$.

165. Wring, S. A.; Hart, J. P.; Analyst 1992, 117, 4.

166. Golderg, H.D.; Brwown, R.B.; Liu, D.P.; Meyerhoff, M.E.; Sens. Actuators B 1994, 21, 171.

167. Kissinger, P.T.; Analyst 1994, 119, 874.

168. Wang, J.; Analyst 1994, 119, 763.

169. Nascimento, V.B.; Angnes, L.; Quim. Nova 1998, 21, 614.

170. Wang, J.; Tian, B.M.; Nascimento, V.B.; Angnes, L.; Electrochim. Acta 1998, 43, 3459.

171. Wang, J.; Nascimento, V.B.; Liu, J.M.; Park; D.S.; Angnes, L.; Electroanalysis 1996, 8, 635.

172. Freire, R.S.; Duran, N.; Wang, J.; Kubota, L.T.; Anal. Letters 2002, 35, 29.

173. Hidalgo, P.; Gutz, I.G.R.; Talanta 2001, 54, 403.

174. Aguiar, M.A.S.; Marquez, K.S.G.; Gutz, I.G.R.; Electroanalysis 2000, 12, 742 .

175. Matos, R.C.; Gutz, I.G.R.; Angnes, L.; Fontenele, R.S.; Pedrotti, J.J.; Quim. Nova, 2001, 24, 795.

176. Rocha, J.R.C.; Angnes, L.; Bertotti, M.; Araki, K.; Toma, H.E.; Anal. Chim. Acta 2002, 452, 23.

177. Matos, R.C.; Pedrotti, J.J.; Angnes, L.; Anal. Chim. Acta 2001, $441,73$.

178. Matos, R.C.; Augelli, M.A.; Lago, C.L.; Angnes, L.; Anal. Chim. Acta 2000, 404, 151.

179. Castro, S.S.L.; Balbo, V. R.; Barbeira, P. J, S.; Stradiotto, N.R.; Talanta 2001, 55, 249.

180. Roston, D.A.; Shoup, R.E.; Kissinger, P.T.; Anal. Chem. 1982, 54, 1417A.

181. Silva, A.F.; Quim. Nova 2003, 26, 56.

182. Smyntyna, V.; Golovanov, V.; Kaciulis, S.; Mattogno, G.; Righini, G.; Sens. Actuators 1995 , 25, 628.

183. Qu, W.; Meyer, J. U.; Meas. Sci. Technol. 1997 , 8, 593.

184. Maekawa, T.; Tamaki, J.; Miura, N.; Yamazoe, N.; J. Mater. Chem. 1994, 4, 1259.

185. Rumyantseva, M.N.; Labeau, M.; Senateaur, J.P.; Delabouglise, G.; Boulova, M.N.; Gaskov, A.M.; Mater. Sci. Eng. 1996, B 41,228 .

186. Devi, G.S.; Manorama, S.; Rao, V.; J. Electrochem. Soc. 1995, 142,2754 . 
187. Fleischer, M.; Meixner, H.; Sens. Actuators 1995 , B26, 81.

188. Lacy, C. de; Benjamin, P.J.; Evans, P.; Ratcliffe N. M.; Analyst 1996, 121, 793.

189. McNeil, C.J; Athey, D.; Ball, M.; Ho, W.O.; Krause, S.; Armstrong, R.D.; Wrigth J.; Rawson, K.; Anal. Chem. 1995, 67, 3928.

190. Plog, C.; Maunz, W.; Kurzweil, P.; Obermerier, E.; Scheibe, C.; Sens. Actuators 1995, 25, 403.

191. Kurzell, P.; Maunz, W.; Sens. Actuators 1995, 25, 653.

192. Souto, J.; Mendez, M.L. R.; Gonzalez, J. S.; Saja, A.J.; Thin Solid Films 1996, 284, 888.

193. Akiyama, H.; Toko, K.; Yamafuji, K.; Jpn. J. Appl. Phys. 1996, 135, 5516.

194. Golding, F.G.; Giallorenzo, M.; Moreno, N. V.; Chang V.; Sens. Actuators 1995, A47, 337.

195. Hodgson, A.J.; Wallace, G.G.; Trans. Mater. Res. Soc. Jpn. 1994, 15A, 681.

196. Fleischer, M.; Meixner, H.; Sens. Actuators 1995, B25, 544.

197. Joo, J.W.; Lee, J.H; Park, S.J.; Sens. Mater. 1995, 5, 371.

198. Hellmich, W.; Bosch, V.; Braummuehl, C.; Mueller, G.; Sverveglieri, G.; Berti, M.; Perego, C.; Thin Solid Films 1995, $263,231$.

199. Hu, X.; Zhang, W.; Rare Met. 1995, 14, 179.
200. Fujimoto, C.A.; Hayakawa, Y.; Ono, A.; Sens. Actuators, 1996, B32, 191.

201. Souteyand, E.; Martin, J. R.; Martelet, C.; Sens. Actuators 1994, B20, 63.

202. Silva, M.S.; Zhang, Y.; Hesketh, P.J.; Maclay, G.J.;. Gendel, S. M.; Stetter, J.R.; Biosens. Bioelectron. 1995, 10, 675.

203. Almeida, F.V.; Guimarães, J.R.; Jardim, W.F.; J. Environ. Monitor. 2001, 3, 317.

204. Fatibello, O.; Borges, M.T.M.R.; Anal. Chim. Acta 1998, 366, 81.

205. Fornaro, A.; Islani, P.C.; Gutz, I.G.R;. Atm. Environ. Part BUrban Atmosph. 1993, 27, 307.

206. Reis, B.F.; Vieira, J.A.; Krug, F.J.; Gine, M.F.; J. Braz. Chem. Soc. 1997, 8, 523.

207. Tubino, M.; Barros, F.G.; J. Assoc. Off. Anal. Chem. 1991, 74, 346.

208. Sene, J.J.; Stradiotto, N.R.; Zeltne, W.A.; Anderson, M.A.; Sensors Actuators 2002, 87, 868.

Received: October 19, 2002

Published on the web: April 17, 2003

FAPESP helped in meeting the publication costs of this article. 